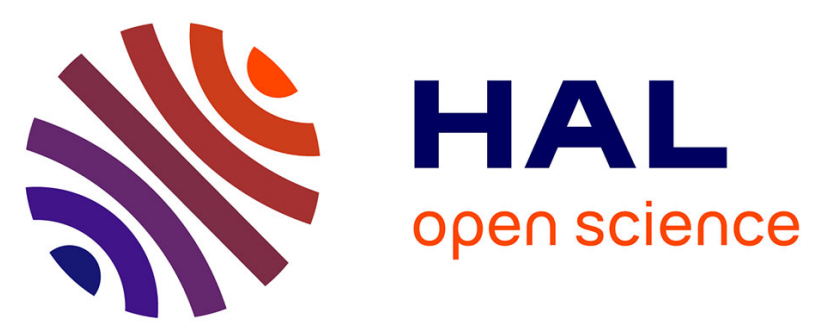

\title{
First contribution of the excavation and chronostratigraphic study of the Ruways 1 Neolithic shell midden (Oman) in terms of Neolithisation, palaeoeconomy, social-environmental interactions and site formation processes
}

Jean-François Berger, Raphaelle Guilbert-Berger, Marrast Anaïs, Olivia Munoz, Guy Hervé, A. Barra, J.A. Lopez Saez, S. Pérez-Díaz, Marjan Mashkour, K. Debue, et al.

\section{To cite this version:}

Jean-François Berger, Raphaelle Guilbert-Berger, Marrast Anaïs, Olivia Munoz, Guy Hervé, et al.. First contribution of the excavation and chronostratigraphic study of the Ruways 1 Neolithic shell midden (Oman) in terms of Neolithisation, palaeoeconomy, social-environmental interactions and site formation processes. Arabian Archaeology and Epigraphy, 2020, Special Issue: The Neolithic of the Arabian Peninsula (Guest Editor: Rémy Crassard), 31 (1), pp.32-49. 10.1111/aae.12144 . halshs02375847

\section{HAL Id: halshs-02375847 \\ https://shs.hal.science/halshs-02375847}

Submitted on 8 Dec 2020

HAL is a multi-disciplinary open access archive for the deposit and dissemination of scientific research documents, whether they are published or not. The documents may come from teaching and research institutions in France or abroad, or from public or private research centers.
L'archive ouverte pluridisciplinaire HAL, est destinée au dépôt et à la diffusion de documents scientifiques de niveau recherche, publiés ou non, émanant des établissements d'enseignement et de recherche français ou étrangers, des laboratoires publics ou privés. 


\section{First contribution of the excavation and chronostratigraphic study of the Ruways 1 Neolithic shell midden (Oman) in terms of Neolithisation, palaeoeconomy, social-environmental interactions and site formation processes}

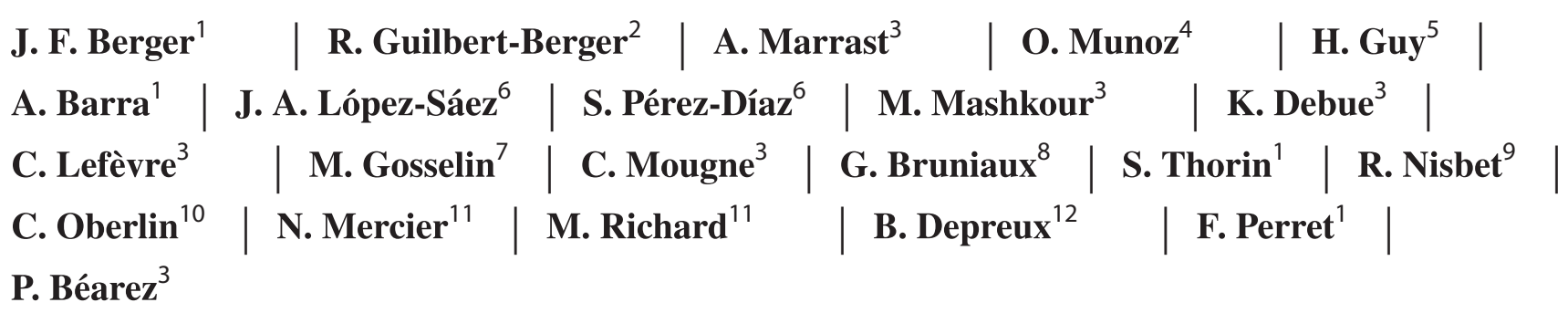

${ }^{1}$ CNRS, UMR 5600 EVS-IRG, University of Lyon, Lyon, France

${ }^{2}$ INRAP PACA, UMR 5133, University of Lyon, Lyon, France

${ }^{3}$ CNRS, UMR 7209 MNHN, Paris, France

${ }^{4}$ CNRS, UMR 7041, MAE, Nanterre, France

${ }^{5}$ INRAP PACA, centre N. Elias, Marseille, France

${ }^{6} \mathrm{CSIC}$, Instituto de Historia, Madrid, Spain

${ }^{7}$ CNRS, UMR 6566 CReAAH, Archéosciences, Univ. Rennes 1, Rennes, France

${ }^{8}$ UMR 7266 LIENSs, Univ. La Rochelle, La Rochelle, France

${ }^{9}$ Viale Rimembranza 7, 10066 Torre Pellice, Torino, Italy

${ }^{10}$ CNRS, UMR 5138 ARAR, MOM, Lyon, France

${ }^{11}$ CNRS, UMR 5060, IRAMAT-CRP2A, Université Bordeaux Montaigne, Pessac, France

${ }^{12}$ UMR 5140 ASM, Université Paul Valéry Montpellier 3, Montpellier, France

Correspondence

J. F. Berger, CNRS, UMR 5600 EVS-IRG, University of Lyon, Lyon, France

Email: Jean-Francois.Berger@univ-lyon2.fr

Funding information

Agence Nationale de la Recherche, Grant/Award Number: ANR-16CE03-00007; French National Research Agency; Ministère de la Culture et de la Communication
The NeoArabia project tries to understand how environmental, social, economic and technological factors work in concert to influence settlement and abandonment along a latitudinal transect of $1200 \mathrm{~km}$ from UAE to southern Oman. This region was affected by wide north-south variations in the Indo-Arabian monsoon, marine upwelling activity and eustatic variations in the Mid-Holocene. On the local settle ment scale, this transect is based on fine stratigraphic excavations and permits the reconstruction of the site formation processes and site catchment analysis. A large number of studies have been conducted on the Ruways- 1 site, focusing on a deep stratified sequence corresponding to three millennia of occupation. These studies include on-site climate-environmental signal analysis, local palaeogeography and environmental reconstruction, reservoir effect studies, typo-technological studies, palaeoeconomic strategies, anthropological studies, sclerochronological studies and, finally, site formation processes, the understanding of which makes it possible to explain the potential and limits of the archaeological excavation. The first results 
confirm the richness of these archaeological archives for documenting the socio-en vironmental dynamics, but also the richness of its complex sedimentary structure and the importance of conducting fine and multidisciplinary excavations to answer questions about the rhythms and functions of occupations and the causalities of socioenvironmental changes.

\section{KEYWORDS}

Coastal Neolithic, geoarcheology, shell midden, site catchment, site formation processes, Sultanate of Oman

\section{\begin{tabular}{l|l}
1 & INTRODUCTION
\end{tabular}}

The French Agence nationale de la recherche (ANR) NeoArabia research project is an international multidisei plinary and multiscalar project that questions whether $\epsilon$ li matic and environmental changes could be an explanation for Neolithic cultural developments (c. 6500-2800 yr BC), and whether the populations of eastern Arabia developed specific modes of adaptation to increase their resilience to mid-Holocene climatic variability. In this perspective, a con textual and interdisciplinary work is being conducted in the search to construct a viable Neolithic coastal fisher-gath erer-pastoral model. This work is based on the excavation of fine sedimentary units and a broad interdisciplinary practice combining archaeosciences (geoarchaeology, archaeozøol ogy, archaeobotany, and geochronology) and the analysis of material culture. Nevertheless, little is known of the charac teristics of the coastal sites, the spatial pattern of mobility of the populations, and the activities they practised. Indeed, in the world of Arabian archaeology, few excavations have been planned from the perspective of environmental archaeology and site formation processes, with the main effort most often focusing on the study of material culture and its diffusion, especially economic and ritual aspects (tombs).

The Ruways-1 (RWY-1) shell middens excavation stim ulated several themes of complementary analyses on a vast mid-Holocene stratified archaeological archive of 8 ha, and we will present the spectrum of these ongoing studies in this paper. The RWY-1 site, located between the Oman Sea and a vast paleo-lagoon supplied by several wadis from the Jabal Safran, was occupied over nearly three millennia (from the end of the seventh to the fourth millennium yr BC). It provides an opportunity to better understand the develop ment of the Arabian Neolithic through its long sequence of occupation, its sedimentary strength (2-3-m depth), and the presence of a very old Neolithic level at the base of the site (6300-6100 yr BC), whose status and cultural charae terisation are still under discussion in the absence of lithic fossil-directors. The combination of stratigraphic excavation and a large geoarchaeological study of the entire site allows us to understand the site formation process and the spatial distribution of the occupations according to cultural periods (helped by the presence of many artificial stratigraphic sec tions created by the exploitation of a quarry).

We here summarise the different tasks in progress on the current RWY-1 excavation and attempt to draw up their main contributions to the practice of multidisciplinary and inte grated environmental archaeology. We discuss the impact of the site formation processes for the analysis of archaeological archives, and their contribution to the elaboration of a socioenvironmental discourse on the coastal Neolithic resiliency of Eastern Arabia.

\section{NEOLITHIC ARABIAN COASTAL ARCHAEOLOGY CONTEXT AND STATE OF THE ART}

Along the Oman coast, the concept of a "Neolithic package" is questionable, pottery is absent and evidence for sedentism is poor (Crassard \& Dreschler, 2013); only the presence of domesticated animals in archaeozoological assemblages, the lithic and beads technics and network developments and a certain vision of the socio-environmental space permits the labelling of these groups in Arabia as Neolithic. Coastal en vironments and marine resources were an important factor in Neolithic development, notably because they presented an apparent resilience to climatic variations. The explanation of cultural changes under climato-environmental constraints has been the subject of numerous academic debates, particu larly since the advent of the processual approach (Binford \& Binford, 1968; Cleuziou \& Tosi, 2000; Renfrew \& Bahn, 2013) and the recent theorisation of a deterministic expla nation of cultural changes (Clare et al., 2008; Cullen et al., 2000; Weiss et al., 1993), which have recently been modu lated by hypotheses favouring more societal adaptation and bifurcation processes (Berger \& Guilaine, 2009). Several archaeology-related studies have since been dedicated to the production of specific data on societal vulnerability and adaptation during the early-mid-Holocene (Berger et al., 2016; Borrell, Junno, \& Barceló, 2015; Flohr et al., 2016). However, few of them have been concerned with the Arabian 
Peninsula and the context of coastal areas (Parker \& Goudie, 2008; Preston et al., 2012). As environmental variability has to be considered an integral part of the historical process (Butzer, 2012; Le Roy Ladurie, 1981), the confrontation between human and climato-environmental trajectories is be coming imperative, although the chronology of both is often approximate, which then complicates a robust discussion of causalities. Some environmental systems are more resilient than others to anthropogenic or climatic changes and their cascading feedbacks (Butzer, 2012). The determination of a precise lagoon, estuary and mangrove ecosystems history is ongoing along the eastern Arabian coast, and the progres sive disappearance or reduction in these habitats will soon be documented, allowing the detection of new keys to discuss societal-environmental interactions. There is little doubt that the presence of mangrove swamps played a fundamental role in the selection of areas where settlements were established. Many of the Neolithic sites lie at the mouth of wadi deltas or estuaries that supplied fresh water, and were therefore sub ject to rapid coastal sedimentation (Berger et al., 2013; Biagi \& Nisbet, 1999; Woodroffe, 1983). As a consequence, their subsistence economy was often based, almost exclusively, on the exploitation of marine and mangrove swamp resources (Biagi \& Nisbet, 2006; Munoz, 2017; Zazzo, Munoz, \& Saliège, 2014; Zazzo et al., 2016). The Arabian Sea mangroves can be considered to have been highly productive on many levels for the prehistoric subsistence economies (Berger et al., 2013; Biagi \& Nisbet, 2006; Tengberg, 2005).

The interaction between humans and their environment operates over a number of different spatial and temporal scales, and evidence for these is apparent in eastern Arabia, where the sub-arid to arid zone was subject to rapidly chang ing environmental conditions after the onset of the humid period around 7000 yr BC (Parker \& Goudie, 2008). Firstly, the region is located in the frontier zone between dry and wet tropical systems where the monsoon has reduced its activity and gradually shifted southward (Yemen) since the middle Holocene (Fleitmann et al., 2007, Lézine et al., 2017), and it has constantly been impacted by the dynamics of the vast marine upwelling off Oman (regional scale of the system). The NeoArabia ANR project is based on the consideration that the shell midden archives of the eastern Arabian coast allow us to explore through time the modes of societal adapt ability in stress conditions in an intra-site-specific context (local scale). Nevertheless, the understanding of their spatial organisation and their mode of accumulation must be well understood beforehand.

Regional chronocultural patterns defined by cumulative probability density function (CPDF) techniques often appear insufficient for characterising socio-environmental relation ships with climate and environmental changes (Berger et al., 2016; Flohr et al., 2016). With extensive application of stra tigraphy, as well as spatial analysis at the site scale, the in-site approach aims to reveal continuity/discontinuity in occupa tion and cultural changes with sensitive timing. Systematic intra-site stratigraphic, taphonomic, and geochronologic evaluations should reveal more robust data to verify whether site abandonment or abrupt decreases in occupation density are real, and not artificially created by insufficient control of the site formation processes or poor control of absolute chronology (Berger, Metallinou, \& Guilaine, 2014; Lespez et al., 2016; Marciniak et al., 2015). It was with this in mind that a stratigraphically controlled excavation at RWY-1 was de cided on, facilitated by the presence of numerous artificially created sedimentary stratigraphies created during quarrying works. This combined approach of archaeological surveys and systematic chronostratigraphic studies should provide extensive knowledge on the site's occupation, facilitating comparisons with off-site studies of the coastal archives.

\section{GEOMORPHOLOGICAL, ARCHAEOLOGICAL AND STRATIGRAPHICAL CONTEXTS OF THE RWY-1 SITE}

The Neolithic RWY-1 shell midden (governorate of alSharqquiyah, Sultanate of Oman) is located in the centre of a wide open and flat north-east-south-west coastline combin ing many wadi estuaries with vast sabkhas, many kilometres in size, which are largely invaded by a system of barchanoid dunes (Fig. 1a). Previous works showed that large midHolocene lagoons and sedimentary mangrove archives were preserved under the surface of these recent sabkhas, with these having being fed by more perennial and powerful wadis under monsoon control (Berger et al., 2013). The surface of the RWY-1 shell midden is estimated to be nearly 8 ha, and its height in relation to the sabkha that borders it to the west and the current marine beach to the east is about 8-10 $\mathrm{m}$ (Fig. 1b). This site has been prospected on the surface for 20 years by the "Ja'alan-Dhofar" French Archaeological Mission in the Sultanate of Oman, to characterise the age and potential duration of occupation (sixth-fourth millennia yr BC). It has now been excavated over the past 3 years in the context of the NeoArabia ANR project, in collaboration with the Ministry of Heritage and Culture of Oman. The site was heavily dam aged at the beginning of 2010 by bulldozers obtaining ballast for public works. This destruction of nearly half of the site surface has presented the opportunity to observe long eon tinuous stratigraphic sections. The front of the ballast quarry has created an observable semi-circular stratigraphic section nearly $80 \mathrm{~m}$ in length and $3 \mathrm{~m}$ in height in the eastern part of the shell midden (Fig. 1b). Around $90 \%$ of the western part of the site has been destroyed, but we were able to observe, record and sample its stratigraphy in 2013-2014, before its near total destruction. 

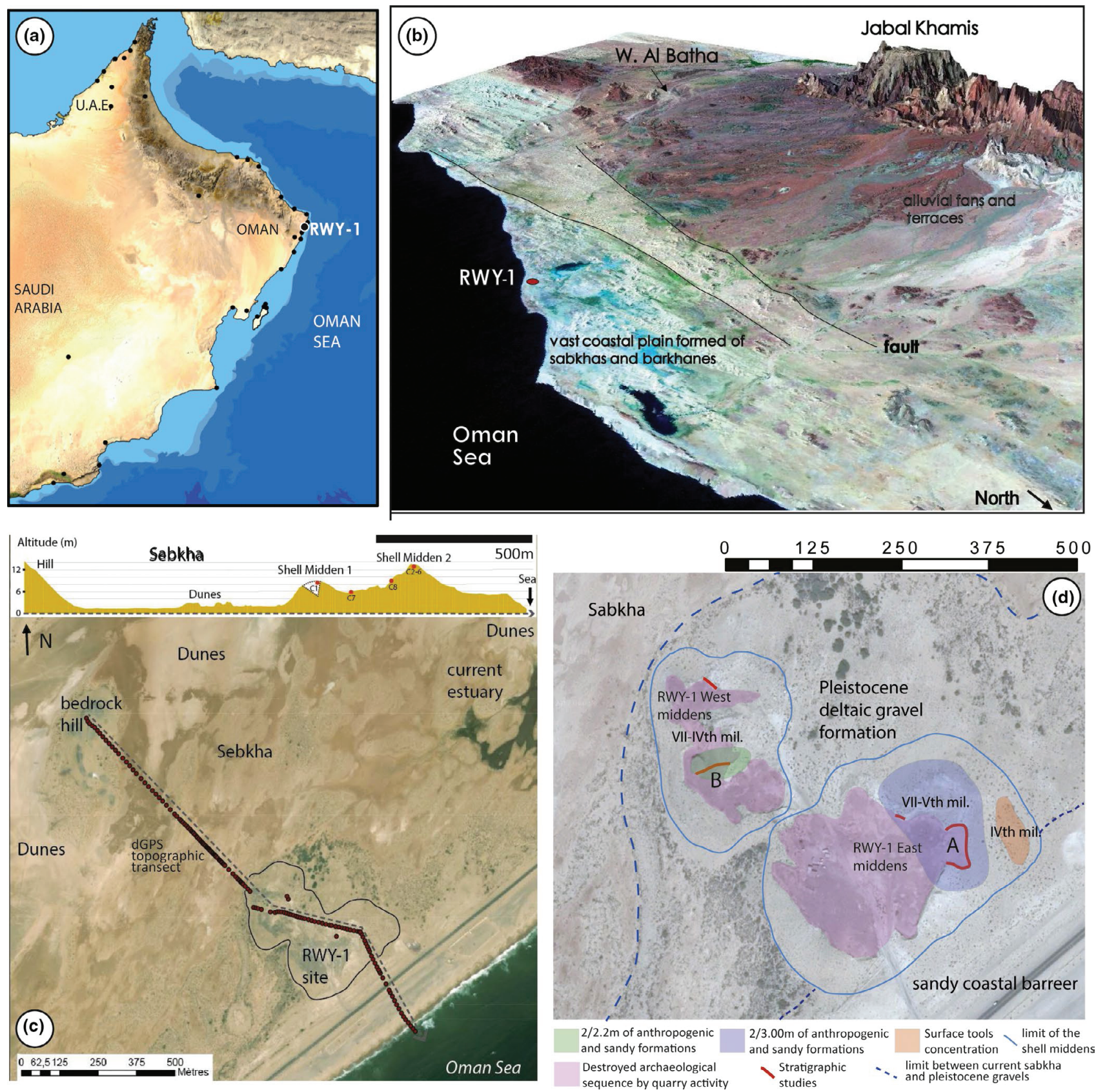

FIGURE 1 (a) Location of the RWY-1 site in the eastern Arabian region with the main archaeological sites studied in the NeoArabia Project (black circles). (b) 3D view of Ja'alan from the north-east with the main geological units, the geological faults, the current coastal sabkhas and the site of RWY-1. (c) Zoom-in of a Google Earth satellite image with the trace of the RWY-1 site and the position of a bpographical dGPS transect between the Oman Sea and the bottom of the sabkha. The yellow topographic profile at the top reveals the presence of two successive shell middens (SM1 and SM2), culminating at 10 and $12 \mathrm{~m}$ respectively. (d) A focus on the spatial organisation of the RWY-1 shell midden, located on a cemented Pleistocene gravelly alluvial formation, shown on a Google Earth framework with the locations of the main stratigraphic studies (see a and b in Fig. 2) and archaeological formations dated by millennium [Colour figure can be viewed at wileyonlinelibrary.com]

Zooming in on the appropriate google images allows the current situation of the site to be observed, showing the heavy impact from the recent extension of a gravel quarry, which destroyed more than half of the initial sur face of the site (see the pink areas; Fig. 1d). The area in blue contains archaeological remains from the seventh to fifth millennium $\mathrm{yr} B C$, the green area remains from the seventh to fourth millennium $\mathrm{yr} \mathrm{BC}$, and the orange area a concentration of remnants from the fourth millennium, mainly identified on the surface.

This type of systematic stratigraphic approach, associated with a geochronological study, is very rarely addressed by 

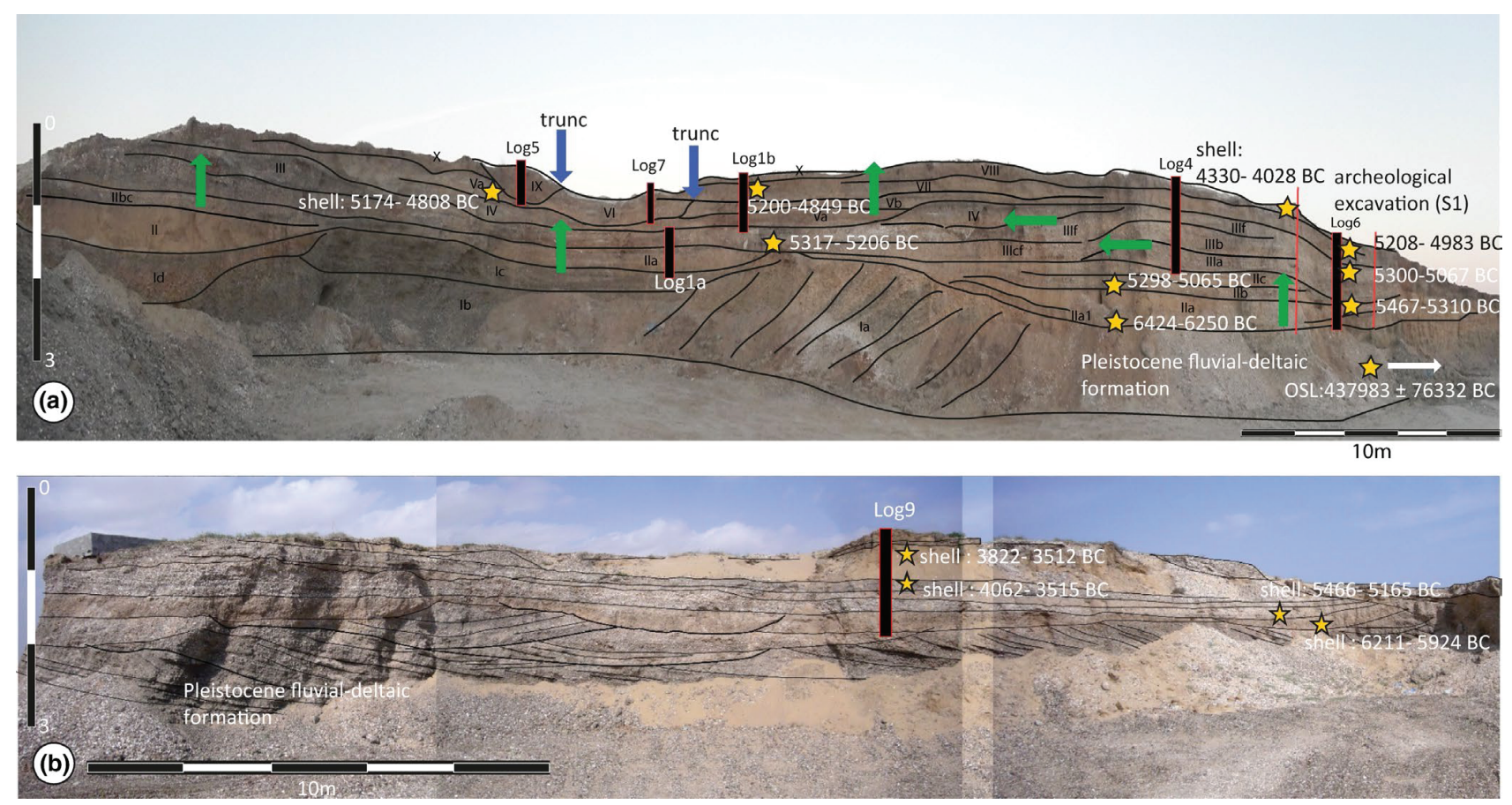

FIGURE 2 The two main stratigraphies of the RWY-1 site. (a) Eastern stratigraphy of the site $(60 \mathrm{~m})$ with the location of the main sedimentary units, the geologically analysed sequences (log), and a part of the radiocarbon dating series in cal yr BC age (mainly on charcoal, except those noted as being from shell). The vertical green arrows indicate a vertical aggradation, the horizontal arrows a lateral aggradation, and the blue arrows a truncation process (versus deflation corridors). (b) Western part of the site $(30 \mathrm{~m})$ with the same data and a clear bi-partition between ${ }^{14} \mathrm{C}$ dates of the seventh-sixth millennia yr $\mathrm{BC}$ and those of the fourth millennium yr BC. No radiocarbon dates from the fifth millennium were recorded in this sequence (this could be due to either absence or destruction of the archaeological sequence) [Colour figure can be viewed at wileyonlinelibrary.com]

Arabian Neolithic archaeology, because of the often small size of the excavations, which are often constrained by very thick and complex archaeologically stratified sequences. Indeed, few excavation areas larger than 10 mexist (Borgi et al., 2012; Cavulli \& Scaruffi, 2012) outside the preven tive archaeology context (Marcucci, Badel, Genchi, Munoz, Todero, \& Tosi, 2014; RAA, Usai, 2006), and most of the studies conducted in Ja'alan over the past 40 years are one-off surveys of less than $5 \mathrm{~m}^{2}$ and are too punctual (Charpentier, Blin, \& Tosi, 1998; Charpentier et al., 2013). Unfortunately, such contexts do not make it possible to ensure that the-ex cavations carried out were properly representative. This has been the case on very rare occasions, and for more recent periods and contexts with significantly reduced sedimen tary thicknesses more favourable to extensive archaeologi cal stripping (Azzarà, 2013; Cattani et al., 2019; Cavulli \& Scaruffi, 2012).

The overall plan is to conduct an excavation strictly mod elled on the previously detailed stratigraphic sequence for analysis of the continuous rhythmicity of occupation from the many visible sedimentary strata (passes of $3-5 \mathrm{~cm}$ ), with a view to determining, as soon as possible, the socio-environmental strategies developed by the Neolithic populations, revealing the technical and economic variations of their occupation through the analysis of material culture, wildlife and ecofact remains that are present at a very high chronological resolution (from 25 to 5 years). The aim is to enable a comparison with off-site palaeoenvironmental data documenting the evolution of the environment and climate in nearby palaeo-lagoon-ar chives, to reveal the causes of socio-environmental phenom ena. The precision of the excavation depends mainly on the sedimentation rate, and the equilibrium between the speed of aeolian sedimentation and that of anthropogenic deposition. In RWY-1, time controls were made from the scale of the site to that of the complex micro-laminated structures of some fire pits (Fig. 1c). Stripping and sampling of layers $1-2 \mathrm{~cm}$ thick, strictly in accordance with the sedimentary structure, were-fa voured, to permit analysis of the rhythmicity and temporality of the deposits (annual and seasonal).

\section{SITE FORMATION PROCESSES}

Understanding the process of formation and post-deposi tional evolution of these complex sites is accessible thanks to the presence of numerous stratigraphical sections artificially dug in the quarry, and a chronostratigraphic framework based on many ${ }^{14} \mathrm{C}$ and optically stimulated luminescence (OSL) 
dates. The effects of natural agents are particularly pro nounced in the arid context, where the protecting vegetation is very sparse and strong winds are very frequent and inten sive. We know by analysis of pollen from the mid-Holocene that ecological conditions were different, being less arid and closer to an arboreal steppe with the presence of man grove ecosystems in the intertidal areas of deltas and estu aries (Lézine et al., 2002). Atmospheric agents such as rain then had a more significant and regular impact, particularly through flooding of estuarine areas. In the shell middens, we therefore have to consider the combined effects of anthropo genic agencies and aeolian processes of deposition, with the shell midden being the product of these two main sedimen tary factors. The thickness and frequency of fire-floor suf faces (in clay fire soles or in pebbles) or pure anthropogenic accumulation from the detritus of consumed products (shells, fish, ashes and charcoal) reflects the density of Neolithic of cupation. These accumulations clearly show the structuring of the intra-site space under the effect of human activities, which can only be partially understood during punctual ex cavations such as ours, but which can be tracked on continu ous stratigraphic transects such as quarry fronts. Sequential and chronostratigraphic analysis of these transects reveals the rhythmicity and time frame of the occupations. Lateral sedimentary progradation can be observed during the densest occupation phases, indicating an extension of the occupied surface. Time is then no longer recorded only vertically, but also laterally (Fig. 2a). Natural post-depositional alterations are also observed, with reprecipitated salts (gypsum) or cal cium carbonates from evaporation of rain being punctual in these semi-arid regions. These are mainly observed on the most ashy facies, which sometimes appear compacted, and are associated with the formation of small millimetric $\mathrm{CaCQ}_{3}$ nodules during moister episodes.

Ten main sedimentary units were observed and dated from the bottom of a shell midden represented by cemented gravels of a Pleistocene fluvial-deltaic sequence ( $>400 \mathrm{ka}$ BP by OSL dating; Fig. 2a). The Neolithic occupation represented by the eastern main shell midden developed between 6300 and $4600-4400 \mathrm{yr} \mathrm{BC}$. The first horizons of occupation are located in Pleistocene relictual palaeochannels filled by yellow aeolian sands (6300-5800 yr BC). The sedimentation of the shell midden shows vertical and lateral aggradation phases, especially in sections relating to the second part of the sixth millennium yr BC, where the anthropogenic deposits are dense. The fifth millennium yr BC is illustrated as being subject to more energetic and destructive aeolian processes, which result in truncation phases to some of the older anthro pogenic formations (Fig. 2a). Erosion by the wind continued until recent times (eighteenth-nineteenth century AD) based on OSL dating (see Section 9). The western shell midden, now totally destroyed by quarrying activity, illustrates a long hiatus between the seventh-sixth millennium yr BC and the fourth millennium yr BC, whose mainly sandy sedimentary formations were deposited following a truncation covering more than a millennium (Fig. 2b).

The impact of wind on sedimentation is almost permanent (a mixture of consumption of debris or charcoal with deposi tion of wind-driven sand), and appears to show fluctuations in intensity (the size and density of particles and of remobil ised artifacts). In phases of greater stability, the effects of the wind appear only in the form of small discontinuous sorted sand beds (perhaps the result of storms?) within otherwise purely anthropogenic formations. During phases of almost continuous wind activity, regular beds of well-sorted hori zontal or oblique small shell debris or fish bones are observed between sandy accumulations. Truncation by wind action is sometimes observed, from the micro-local scale (decimetricsized deflation bowls) to the local scale (deflation corridors over several meters that permanently weaken the shell mid dens; Fig. 2a). In the second case, these probably correspond to hyper-arid periods (cf. unit VI around 5000-4800 yr BC), and the destruction of a large part of the previous formations over several meters is observed. These phenomena compli cate the stratigraphic interpretation of the site.

\section{PALAEOECONOMIC AND SITE CATCHMENT ANALYSES}

The multi-proxy analysis (charcoal, charred seeds, pollen, marine molluscs, crustaceans, fish, turtles, birds, land and marine mammal bones) provides a preliminary reconstruc tion of the subsistence strategies. The faunal remains col lected during the 2017 and 2018 excavations are currently being studied at the laboratory of archaeozoology and archae obotany at the National Museum of Natural History in Paris, using the modern comparative osteological collections for the taxonomic identification of the remains. The results of the archaeomalacological study show that the marine shells are mainly culinary waste (Fig. 3), with the main species being the clam Marcia recens (syn. Marcia marmorata). Several other species were also collected for food on a smaller scale, such as oysters (Ostreidae), the clam Callista umbonella (syn. Amiantis umbonellą, brown mussel Perna perna (syn. Perna picta), crowned turban shell Lunella coronate, and cowry Cypraea sp. The main environment exploited was the muddy sand from the lagoon, used for the gathering of Marcia recens. Marine shells were also used as raw materi als for manufacturing objects like decorative elements, tools, and fishing hooks.

The ichthyological study revealed thousands of small ver tebrae belonging to small fish species or juvenile specimens, which can take refuge in the pneumatophores of the man grove to hide from predators. This illustrates a subsistence activity mainly oriented towards exploitation of the lagoon 


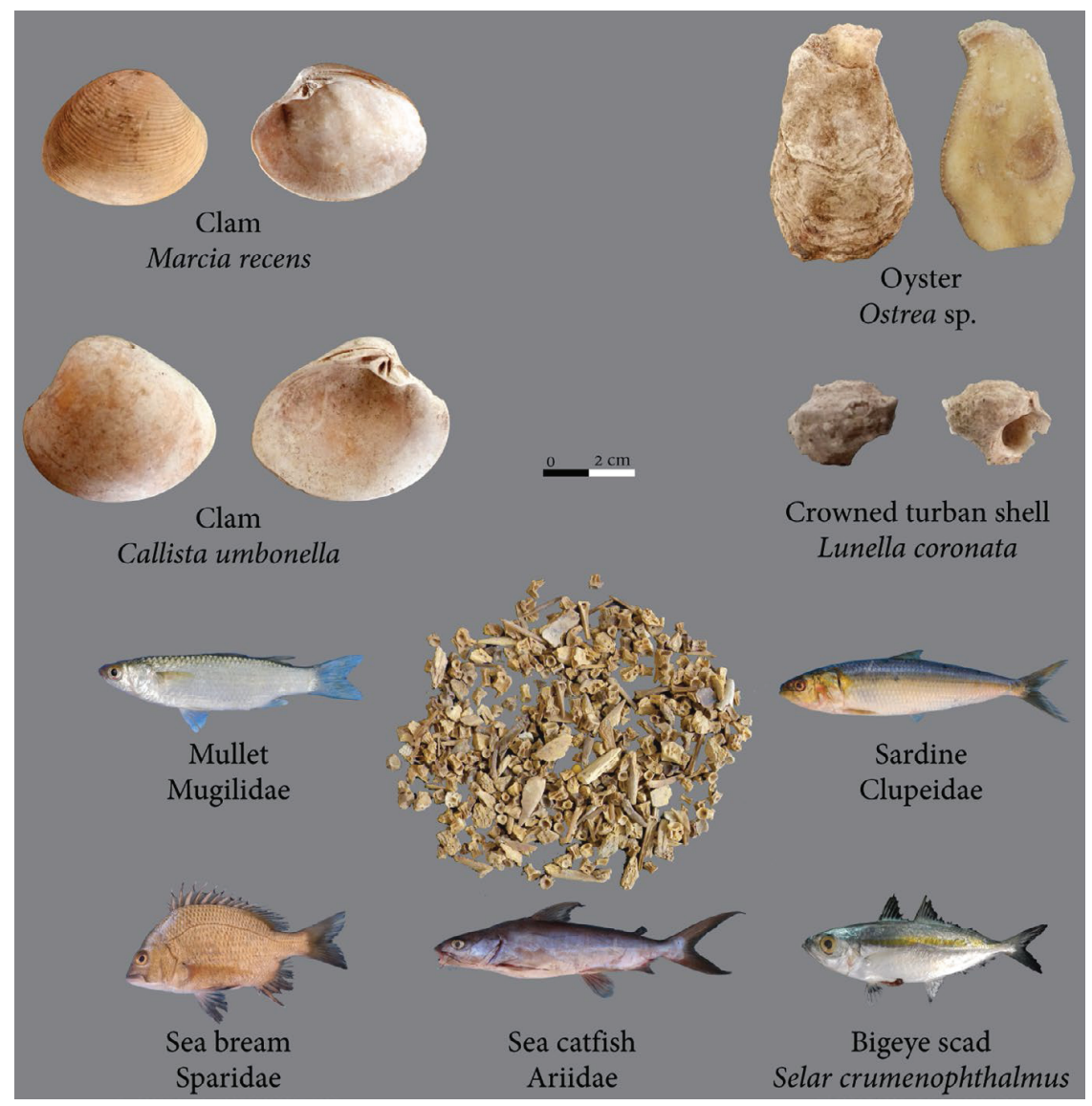

FIGURE 3 Illustration of the main shellfish and fish taxa identified in the first RWY-1 studies. Seashell photographs: archaeological specimens from RWY-1. Fish photographs: fresh fish from the MNHN osteological collection of fish for the Indo-Pacific area [Colour figure can be viewed at wileyonlinelibrary.com]

and mangrove swamps (Fig. 3), with the presence of many mullet (Mugilidae), bigeye scad (Selar crumenophthalmuks and sardines (Clupeidae), as well as many juvenile sea bream (Sparidae) and sea catfish (Ariidae). Neolithic people from RWY-1 probably used fishing nets with small meshes.

These preliminary results of the study of marine re sources show that the Neolithic populations of RWY-1 had a subsistence activity mainly focused on exploitation of the lagoons, which were probably very extensive in the west ern part of the site (see Section 11). RWY-1 appears to be a fishing station where Neolithic communities were able to exploit the entire intertidal zone to collect bivalves, and also to have access to lagoon waters where they could lay their fishing nets, as is the case on other sites on the Ja'alan coast such as SWY-1 (Marrast, Béarez, \& Charpentier, 2020; Martin, 2005).

In general, the preservation of vertebrate remains is poor because of the loss of organic material and high fragmenta tion. Besides fish, the vertebrate assemblage of Ruways 1 is composed of a few mammalian and reptilian remains (Fig. 4). The mammalian remains belonged to ovicaprids, and in some cases it was possible to identify the bones to the level of the species. This is the case for a talus allocated to a goat (Fig. 4: 1). In other cases, it was not possible to distinguish between sheep and goat (Fig. 4: 2). Ruways 1, like other Neolithic sites in Oman, is remarkable for the presence of canid bones among the faunal assemblages. A complete calcaneus of a dog (Fig. 4: 3) and a distal part of a humerus (Fig. 4: 4) were recovered from the site, and highlight once more the impor tance of these taxa for consumption in this part of the world. Other mammals exploited in Ruways are dolphins, a single vertebra of which was recovered practically complete (Fig. 4: 5). Finally, marine turtle bones are also present in the re mains, as demonstrated by a relatively large shell that was consolidated before removal (Fig. 4: 7). This shell belonged to a green sea turtle, common in most of the coastal sites of Oman. Study of the turtle remains is still ongoing.

Analyses of the floral macro-remains have also been performed, specifically the different types of fuelwood obtained from local vegetation communities, with these fuelwood remains being very frequent in the numerous fireplaces or ashy layers of the site. Despite the still par tial data, the charcoal remains reveal that the mangrove environment, which has nowadays disappeared, was pres ent at least until the end of the fifth millennium yr BC. After two seasons of study (2017-2018) and the analysis of two-thirds of the RWY-1 sequence, with more than 1000 charcoal fragments having been analysed, a similar pat tern emerges in the relative presence of taxa, though with some differences (Avicennia occurring in $87 \%$ of the sam ples, Rhizophora in 53\%) in relation to Chenopods. The very limited range of species at the anthracological level 
FIGURE 4 RWY-1 faunal remains, 1: C2 US18. Capra, talus. 2: B2 US18. Caprini mandible fragment of the articulation. 3: $A 2$ US18. Canis sp. Calcaneus. 4: S1 A2 US6B distal humerusCanis sp. 5: B3 US13b dolphin vertebra. 6: B2 US12a long bone (humerus) shaft of a medium-sized ungulate. 7: B2 US11b marine turtle shell [Colour figure can be viewed at wileyonlinelibrary. com]
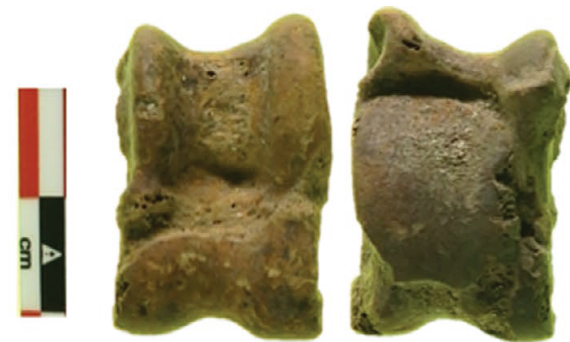

1
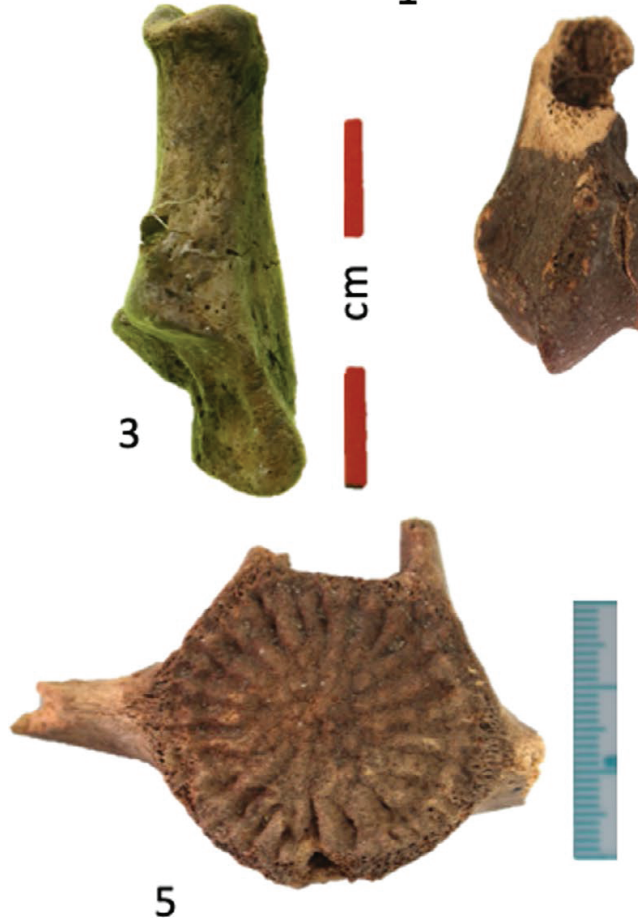
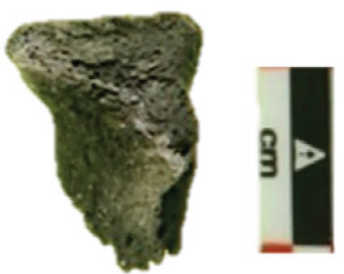

2

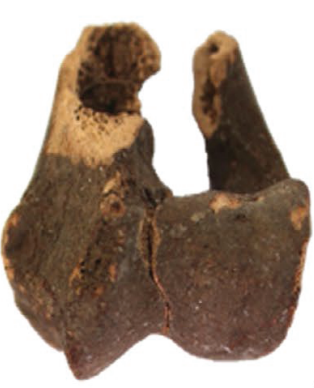

4
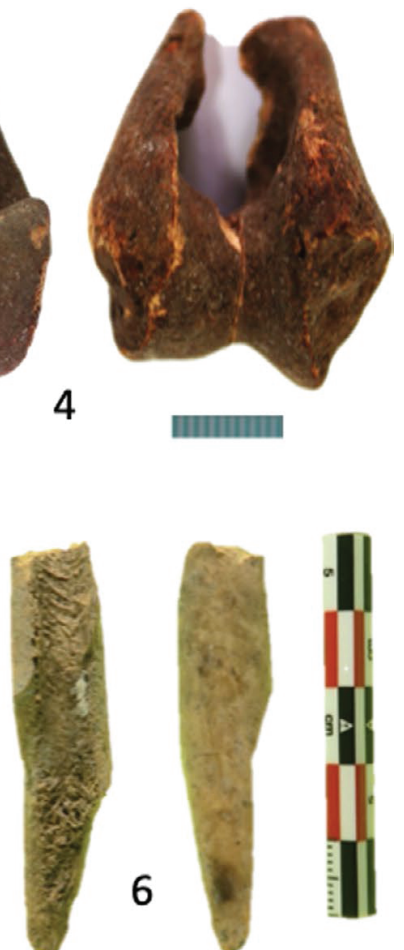

6

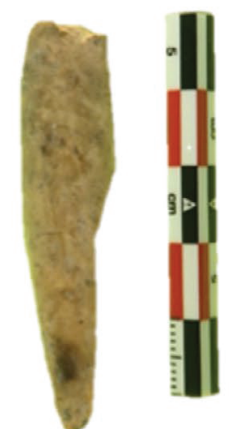

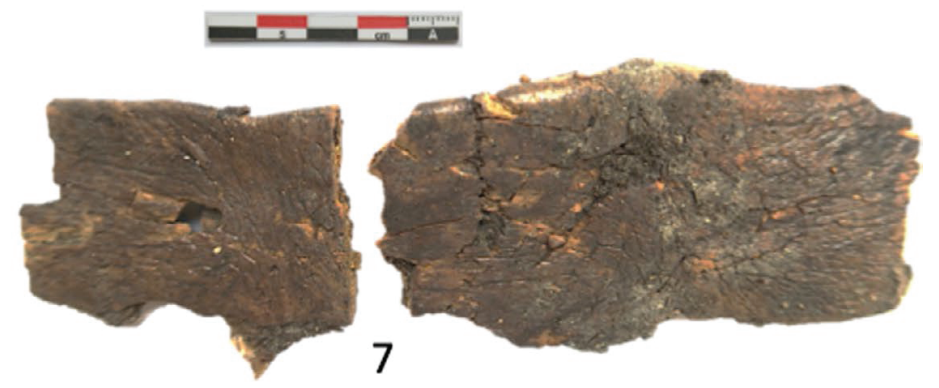

is surprising, given that the other Neolithic sites for which charcoal analyses have been performed generally present a more varied situation (cf. Ras al Hamra 5-6; Biagi \& Nisbet, 1999). This would suggest that mangroves were the only source of timber and firewood for the local groups over a period of several centuries.

The remarkable presence of Rhizophora of mucronatais of note; it is a species no longer growing along the coasts of the Arabian Sea (refuges are found in more humid trop ical areas). Avicennia sp., known to be the most tolerant in terms of environmental conditions, were observed in the region until at least the Early Bronze Age (Cartwright, 2004), and are now present in the Khor al Jaramah (north Ja'alan), where they were recently reintroduced. Their presence confirms results from the pollen assemblages (see Section 10), the frequent presence of mangrove-adapted species like the gastropod Terebralia palustris, and the exploitation by Neolithic peoples of the two arboreal species of mangrove. Further research should provide details on the origin, evolution and death of the local mangroves, which probably locally disappeared at different times and for dif ferent reasons (climatic changes and human pressure). 


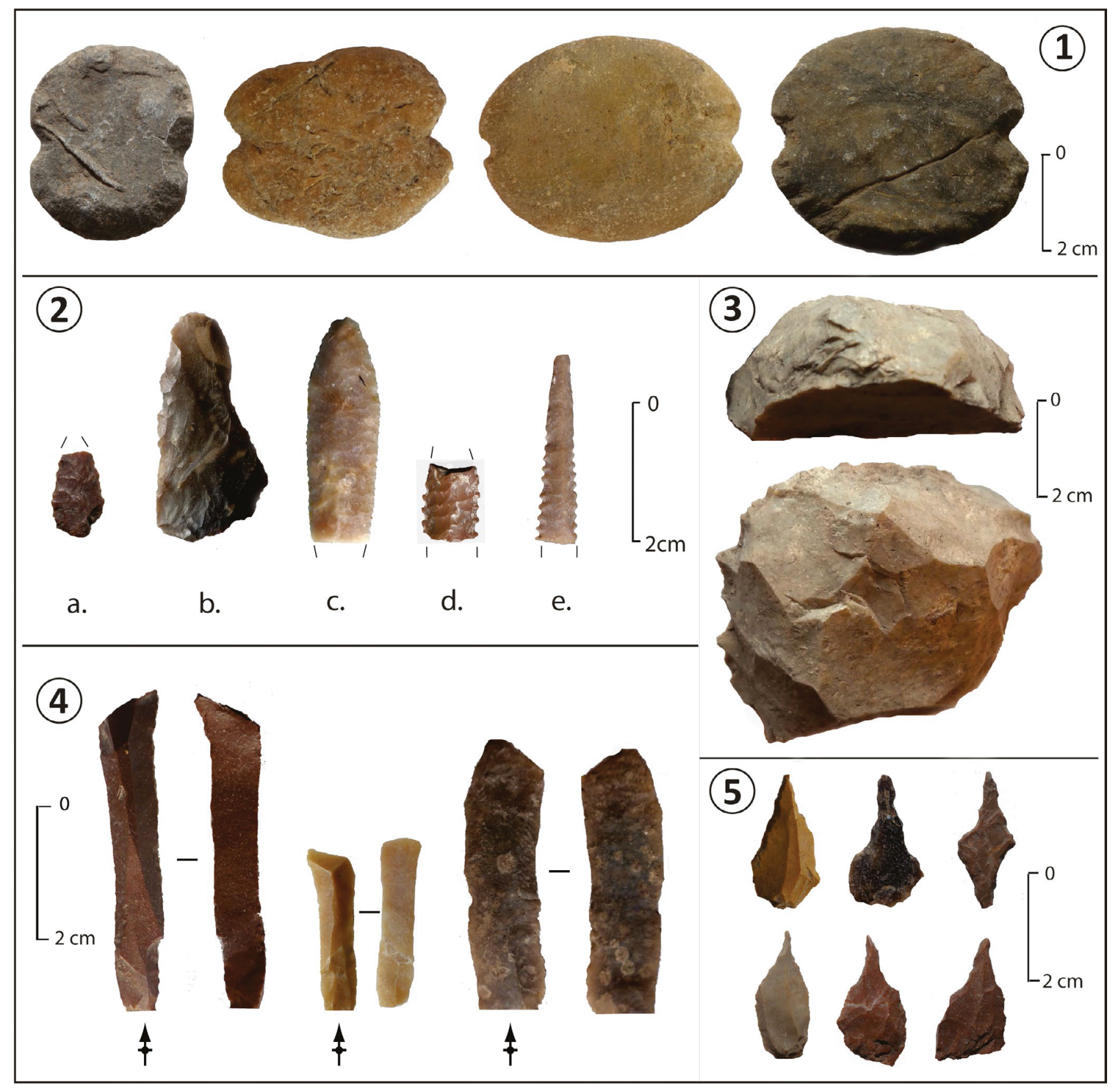

FIGURE 5 Illustrations of the RWY-1 lithic material (from the upper part of the archaeological sequence between 5200 and $4600 \mathrm{yr}$ BC). 1. Net sinkers in sandstone and calcareous rock from the levels 5-6. 2. Arrow heads: a, b, c: bifacial points from levels 6-10d, e: trihedral points from levels 8 and 9 (pressure retouches, around 5100-5200 yr BC). 3. A large scraper. 4. Production of bladelets from a great variety of flint material, with a soft striking debitage (some of them are probably imported in the form of finished products). 5. Presentation of drill points on various flint materials from levels 5-6 [Colour figure can be viewed at wileyonlinelibrary.com]

\section{6}

\section{TYPO-TECHNOLOGICAL STUDIES}

The 16 current levels studied (from 5 to 20 ) from the $3 \mathrm{~m}^{2} \mathrm{~S} 1$ excavation of the Ruways shell midden have already deliv ered 2728 lithic objects (excepted sketches). These include knapped flint pieces, shaped or crushed sandstone or lime stone pebbles, and net sinkers; the whole being associated with numerous beads, faunal remains (including several pol ished bone objects), and a large mass of marine shells, in cluding some used as scrapers.

Throughout the sequence, the Ruways 1 site is character ised by intense craftworking activity, as we were able to iden tify the presence of a workshop for the manufacture of drills and net sinkers, and most probably a workshop for the process ing of beads (which are quite common along the coast of the 

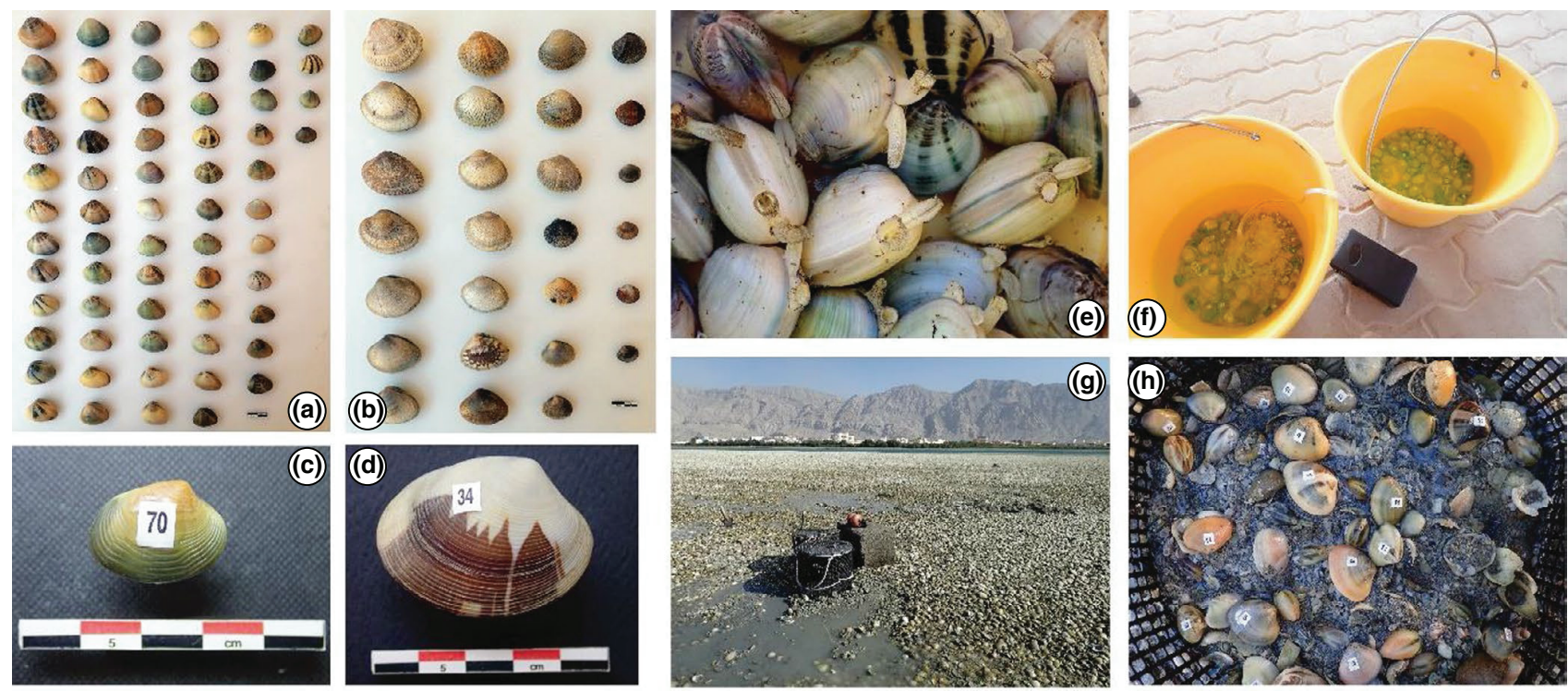

(ii)

(K)

15 January

14 April
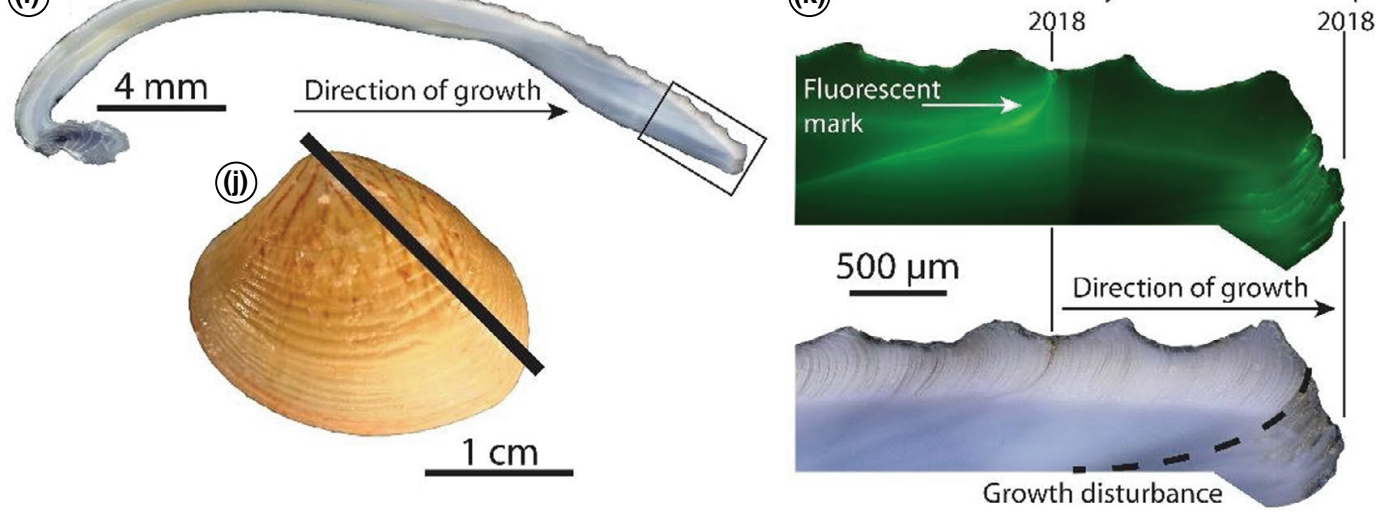

FIGURE 6 Different steps of the marking experiment (a-h) and observation of the growth increment and chemical marking from the thin section of a shell of Marcia recens (\#M.68 from the non-broken cage) marked on 15 January 2018, and taken out of seawater on 14 April 2018 (i-k). ( $a$ and b) Size, colour and form diversity among Marcia recens and Circenita callypiga species. ( $c$ and d) Each of the caught bivalves were tagged, sized and weighed. (e) Bivalves were kept alive in seawater with a compressor system for aeration. (f) Marking was performed in oxygenated seawater with the chemical tag (Calcein) being mixed in and the specimens being exposed to it over $4 \mathrm{~h}$. They were finally rinsed in clear seawater and then kept in oxygenated seawater for an additional $8 \mathrm{~h}$. (g and h) The marked specimens were taken back to their original place of growth and split into two cages where they grew for 89 days. ( $i$ Thin section of a shell demonstrating its birth (umbo, left side) to its death (pallial margin, right side). (j) Left valve of \#M.68. The black line shows the cutting line as well as the piece of shell used to make the thin section. ( $k$ Detail of the end of the growth of specimen \#M.68 (pallial margin) under fluorescent light (upper right panel) and reflected light (lower right panel). The black dotted line shows the beginning of the disturbed growth period [Colour figure can be viewed at wileyonlinelibrary.com]

Arabian Sea) (Brunet, 2015). The site also presents records of many domestic activities related to fishing, hunting and most likely gathering (the presence of a circular cup anvil). Several fireplaces have been identified during the excavations, and these attest to culinary activities. At the same time, the den sity of shaped flint suggests that it was knapped on site, and the fragmentation rate from production, particularly of blades, leads us to consider a high utilisation rate (Fig. 5).

In addition, analysis of the raw materials and economic strategies of the Ruways trimmers' workings revealed the presence of the production of different blanks, particularly in early phases around 5200 yr BC. Moreover, although the great majority of the production remained rudimentary (chips, bladelet chips, small irregular blades), some isolated blades attest to a high degree of expertise and are in sharp contrast with the rest of the shaping industry (Fig. 5). These latter items could testify to importations from specialist workshops at the micro-regional scale.

\section{7 | SCLEROCHRONOLOGICAL STUDY OF BIVALVE SHELLS AND SEASONALITY OF OCCUPATION}

Among the zooarchaeological remains found at RWY-1, molluscs are a well-represented taxon in terms of biodiversity, 
as well as in quantity, forming the so-called "shell middens". Among the bivalve taxa, the Veneridae dominate, witMarcia recens, Callista umbonella and Circenita callipyga. These three species could have been gathered from the intertidal zone at the edge of the mangrove environment. Similar to dendrockro nology, sclerochronology is the study of the testaceous part of biological organisms, such as the shells of molluscs. Growth line patterns and the chemical composition of these shells can provide information on the biology of the species, as well as on the environment in which they grew (Buddemeier, 1978; Gosselin, Lazareth, \& Ortlieb, 2013; Jones, 1983; Schöne, 2008; Wanamaker et al., 2011). In an archaeological context, periods of human residence in coastal settlements can be deduced via de termination of the season of the mollusc catch and paleo-climatic parameters, such as inferred sea surface temperatures (Andrus, 2011). For this purpose, a preliminary calibration study on living specimens was implemented during the winter of 2017-2018 to characterise the growth patterns (e.g. rhythm and variation of growth) of the three bivalve species (Fig. 6: a-h).

The first results of the marking experiments in Oman and UAE provide insights into the respective time frame works of the three species.M. recens, C. umbonella and C. callipyga show a common tidal growth rhythm. After a period of about one monthM. recens and C. callipyga were disturbed in their growth by an environmental event that may have been related to a punctual winter flood (Fig. 6: i-k). Further research on bivalve shells will provide knowt edge on the seasonality of occupation sites and paleo-en vironments, which will be cross-referenced with the other information gathered during this interdisciplinary study.

A regular pattern of Neolithic transhumance between the inland regions and the west coast of what is now the United Arab Emirates has not been proved by analyses of ${ }^{87} \mathrm{Sr} /{ }^{86} \mathrm{Sr}$ ratios of Neolithic skeletons (Kutterer \& Uerpmann, 2017). The pattern of animal exploitation at UAQ2 (Mashkour et al., 2016) also documents a year-round residency on the coast. Mobility to the interior seems to be more associated with herder or hunter pathways than with the general population. For the fourth millennium Ja'alan communities, a micro-re gional seasonal nomadism model is proposed, comparing the different scales of movement with both the territory and-re sources (Cavulli \& Scaruffi, 2013). The cross-discipline ap proach used for the RWY-1 data (fauna, sclerochronology, pollen, geoarchaeology) should provide answers to these-es sential questions, allowing an understanding of the status of sites and Neolithic strategies within the East Arabic region.

\section{8 \\ MIDDLE NEOLITHIC HUMAN REMAINS AND BURIALS AT RWY-1}

During the last survey and excavation season at RWY-1, several human remains were brought to light, most of which were related to burials partially or totally dam aged by the quarry extraction works carried out in the shell midden during recent years. In total, three graves, including three adult individuals and one child aged $4 \pm$ 1 years, were recognisable from human bones cut by the north-western and south-eastern sections in the quarry. A few other scattered human remains were also found in the quarry debris, but these could not be linked to graves in the section. These finds are of considerable interest, be cause their stratigraphic position shows that they belong to the middle Neolithic period, during the second half of the sixth millennium yr BC, for which no other human remains or burial evidence has yet been recovered in Oman. Findings of the most ancient human remains have so far come from the UAE at Faya 10 (Kutterer, 2012), Marawah 11 (Beech et al., 2008) and in the large Neolithic cemetery at Jebel Buhais (de Beauclair, 2008; Uerpmann, Uerpmann, \& Jasim, 2006), with contexts dating from the seventh to fifth millennium yr BC. Although the graves documented at RWY-1 share common characteristics with those known from later sites (pit graves, accompanied by ornaments and faunal remains; see Bortolini \& Munoz, 2015; Marcucci et al., 2014; Salvatori, 2007), some are unique in the position of the individuals. Indeed, in two graves the subjects were placed in a lying position on their backs, which is totally unparalleled in the region. The ongoing anthropological study should provide valuable information on dietary practices and the health status of individuals.

\section{ABSOLUTE CHRONOLOGY AND RESERVOIR EFFECT STUDY}

Sequential analysis has concentrated on the central part of the shell midden, which is highly anthropogenic and about $30 \mathrm{~m}$ long (Fig. 2a). Ruways 1 is already an exceptional site according to the absolute chronological data, as the first Neolithic occupation is very old (late centuries of the seventh millennium yr BC), being confirmed in three parts of the site by two distinct radiocarbon dates on the same level in the log2 sequence (6378-6069 on shellfish with a small aver age delta R value still temporary in RWY-1 (28,625 \pm 58 years) and 6424-6250 on charcoal), and by three OSL dates immediately posterior to this oldest occupation (6323 \pm 485 yr BC to $5725 \pm 583$ yr BC, Richard et al., submitted). The site is more than 6-7 centuries older than the other oldest dates obtained regionally (SWY-1, SWY-11 and SWY-20) (Charpentier, 2008), and five centuries older than the known chronology of Ras dah SM-10 (Masirah Island) (Charpentier et al., 2012).

The second goal in RWY-1 is to develop a specific study on the reservoir effect of the stratified shell accumulations 
dated by the radiocarbon method (with the radiocarbon tab oratory of the University of Lyon and the Artemis National Planning), combining on the same levels the dating of sam ples of lagoon and marine shells and terrestrial charcoals. The complementarity of the OSL method was tested in the sandiest parts of the archaeological sequence, where no char coal was preserved because of an unfavourable environment (Richard et al., submitted). In order to complete the chronol ogy of the site, sediments ( $n=12)$ were sampled in phases I, II, VII, VIII and IX. Ten of these samples were dated using OSL applied to quartz grains; for the two remaining samples, the quartz signal reached or was close to saturation, there fore feldspar grains were dated using their infrared stimulated luminescence signal. The age obtained at the base of the-se quence (phase I) indicates a deposition time during the Middle Pleistocene, before $437 \mathrm{ka}$. For the later phases, luminescence ages indicate that the site was occupied from $6323 \pm 485 \mathrm{yr}$ BC (phase II) to $3225 \pm 275$ yr BC (phase VIII) (Richard et al., submitted). OSL ages obtained for phase IX range from $1389 \pm 186 \mathrm{yr} \mathrm{BC}$ to the modern period (1764 \pm 15 to 1917 \pm 9 AD), suggesting that the sediment from the top of the sequence was recently reworked by wind activity in this area.

For a given region, the difference between the local marine ${ }^{14} \mathrm{C}$ age and the global model marine ${ }^{14} \mathrm{C}$ age is given by $\Delta R$, whose estimation is necessary to calibrate the ${ }^{14} \mathrm{C}$ ages of marine samples. This offset in the local marine ${ }^{14} \mathrm{C}$ ages from the global modelled mean can be determined from the ${ }^{14} \mathrm{C}$ dating of terrestrial material (charcoal, seeds) and marine shell pairs collected from the same stratigraphic horizon. For the moment, our study is based on 12 dates using combined values from the ubiquitous shells ofMarcia recens and charcoal, and 12 dates using the more marine shell Lunella coronata, which are being analysed at the radiocarbon laboratory of Lyon. Preliminary results with low values of $\Delta \mathrm{R}$ (50-150 years) strongly oscillate between the seventh and sixth millennia yr BC; these are very different from previous estimations proposed for the midHolocene period (240-720 years) (Staubwasser et al., 2002; Uerpmann, 1991), but closer to the robust calculations made in an archaeological context for the mid-sixth and the mid-fifth millennium cal yr BC at Ra's al-Hamra 6 where $\Delta \mathrm{R}$ values range from $99 \pm 27$ to $207 \pm 43{ }^{14} \mathrm{C}$ yr (Zazzo et al., 2016), for the forth millennium at Ra's al-Hamra $5(\Delta R=255 \pm 55$ ${ }^{14} \mathrm{C}$ yr; Zazzo et al., 2012; 2014) or for the third millennium yr BC (Early Bronze Age) : $210 \pm 15$ years (Saliège, Lézine, \& Cleuziou, 2005). The forthcoming results should make it pos sible to decide on dates for almost the entire Neolithic period.

\section{IN-SITE CLIMATE AND} ENVIRONMENT SIGNALS

The Ja'alan coast is today associated with an arid tropical desert with sudanian to sub-sudanian vegetation. However, pollen (Lézine et al., 2002, 2017) and geoarchaeological stud ies suggest that the mid-Holocene conditions were different (Berger et al., 2013). Conditions along the eastern Arabian coast have changed, with past latitudinal monsoon circula tion changes through time (Fleitmann et al., 2007; Parker $\&$ Goudie, 2008). Local variation in climatic change is still too rarely attested to archaeological sites or continental river archives close to sites occupied by the first Neolithic com munities of the eastern Mediterranean (Berger \& Guilaine, 2009; Berger et al., 2016; Lespez et al., 2016; Zielhoffer et al., 2012). The inferences for climatic impacts are most often indirect, being derived from glacial, marine or continental ar chives like speleothems (Cremaschi et al., 2015; Cullen et al., 2000; Fleitmann et al., 2007; Staubwasser et al., 2003). One of the purposes of the RWY-1 excavation was to identify cli matic signals recorded in different forms in the sedimentary sequence (by sedimentological, geochemical, palynological, and anthracological techniques).

The fine analysis of anthropogenic and environmental records in the stratigraphies of the shell middens are asso ciated with coherent sedimentological and geochemical sig nals recovered by studies of sequential sedimentations. Eight sequences have been selected from the east to west part of the site along the artificial stratigraphies, to document all the sedimentary processes with the most precision. We have chosen to discuss two of them ( $\log 1 \mathrm{ab}$ and $\log 2)$, to demonstrate their promising potential (Fig. 2a and Fig. 7). Coincidental high bromine/titanium ratios (an indicator of organic matter), high magnetic susceptibility values (an indicator of fire and fireplaces with production of maghemite oxide), total organic matter (loss-on-ignition), and sulphur, characterise the anthropogenic deposits. These show strong correlations with potassium/titanium ratios, which probably represent local-in creases in soil weathering (more atmospheric humidity favourable to anthropogenic deposits in periods of low wind input). Aeolian accumulations by wind activity (in yellow hatching) appear in inverse correlation with anthropogenic indicators (Fig. 7). They are associated with a high rubid ium/titanium ratio, and high D50 (median) and D99 (superior unipercentile) grain size indicator values, which infer an increase in sediment size and wind energy, and together with high values of calcium carbonates indicate carbonates as the main source of the aeolian dust. Two main arid phases are recorded, the first between 6200 and 5300-5200 yr BC, and the second between 5000-4900 and 4200 yr BC. The main an thropogenic production is centred on the period 5300-5200 to $5000 \mathrm{yr} B C$. This diagram also shows the sedimentary con traction of the fifth millennium yr BC in this part of the site, which is better documented in other parts of the site.

Intra-site palynological analysis is used on the same sequences to determine the evolution of the vegetal landscape, the climatic conditions, and in-site anthropogenic activities. In this case, this study is particularly interesting 


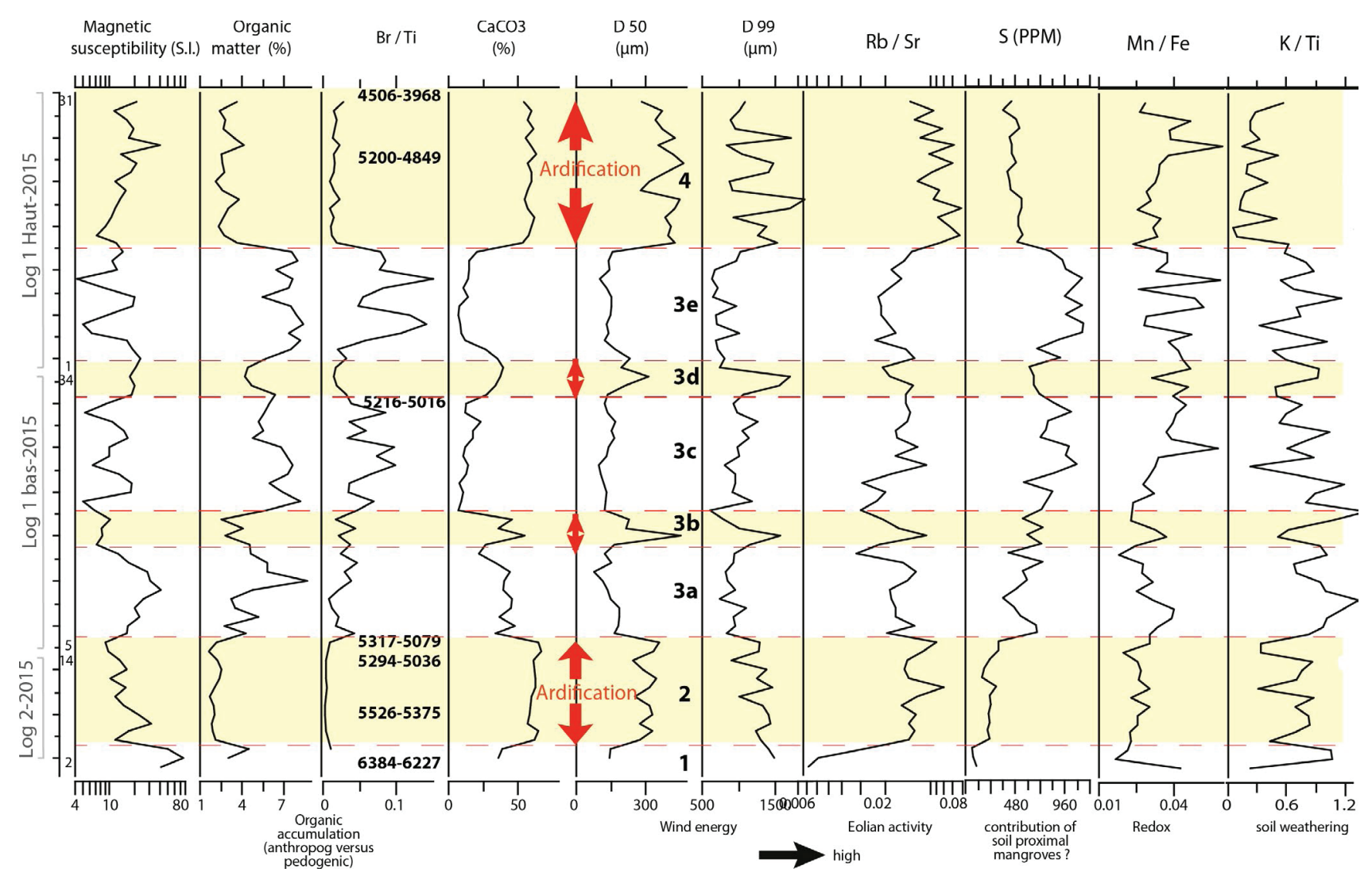

FIGURE 7 Sedimentological and geochemical diagram of $\log 1 \mathrm{a} / \mathrm{b}$ and 2 (western RWY-1 stratigraphic section). Dates are in cal. yr BC [Colour figure can be viewed at wileyonlinelibrary.com]

because of the great scarcity of palynological analysis in the region in relation to global changes, coastal ecosys tems (lagoons, mangroves), fluctuations in marine upwell ing and population concentrations (Lézine et al., 2002). The first results from Ruways 1 ( $\log 1 \mathrm{ab}$ and 2) show different taxa from $5500 \mathrm{yr}$ BC, which can be grouped into five ecological groups. One includes the two man grove taxa (Avicennia and Rhizophora), another the wet land taxa including Cyperaceae,Typha and Tamarix, that is, plants related to a high water table and little salinity in the water. There are a whole series of local and semidesert taxa (Acacia, Aizoaceae, Artemisia, Asteraceae, Calligonum, Chenopodiaceae, Combretaceae,Ephedra, Poaceae, Prosopis, Tribulus and Ziziphus), although Chenopodiaceae may also be related to high concentrations of salt on the surface. There is also a group of regional taxa from the Omani mountains located in the north-east of Ja'alan (Dodonaea Olea europaea type, Podocarpus, Juniperus type, Myrica and Ericaceae), and finally there are the non-pollen palynomorphs of a coprophile nature (Cercophora, Chaetomium Sordaria and Sporoemiella), which confirm the presence of faunal pastoral remains. Regarding evolution, the base of the sequence $(\log 2)$ rep resents a time when the mangroves were much more abun dant than today, reaching their maximum (both Avicennia and Rhizophora). In $\log 1 \mathrm{a}$ and $\log 1 \mathrm{~b}$, the mangroves are reduced, but they are still important, almost always with high values. In the top of $\log 1 \mathrm{~b}$ (fifth millennium yr BC), the mangroves show an abrupt reduction, at the same time as an increase in wetland taxa, Chenopodiaceae, Poaceae and Artemisia, and especially the coprophilous fungi.

\section{LOCAL PALAEOGEOGRAPHY AND ENVIRONMENT RECONSTRUCTION}

Palaeogeographic parameters are affected by physical forces such as sea-level changes, climate and tidal amplitude and duration, as well as the quantity of fresh water inflow asso $\epsilon$ i ated with monsoon systems, which have determined and im pacted the location of settlement networks and the economic strategies of the first Arabian Neolithic populations along the eastern Arabian coast (Berger et al., 2013). Mangrove ecosystems represent a natural resource base for silviculture and a large range of economic products, and also provide habitats for rare fauna (fish, shellfish, birds and crustacean species). Geomorphological and environmental studies have shown that during the middle of the fifth millennium yr BC, a maximal marine transgression caused a major phase of 


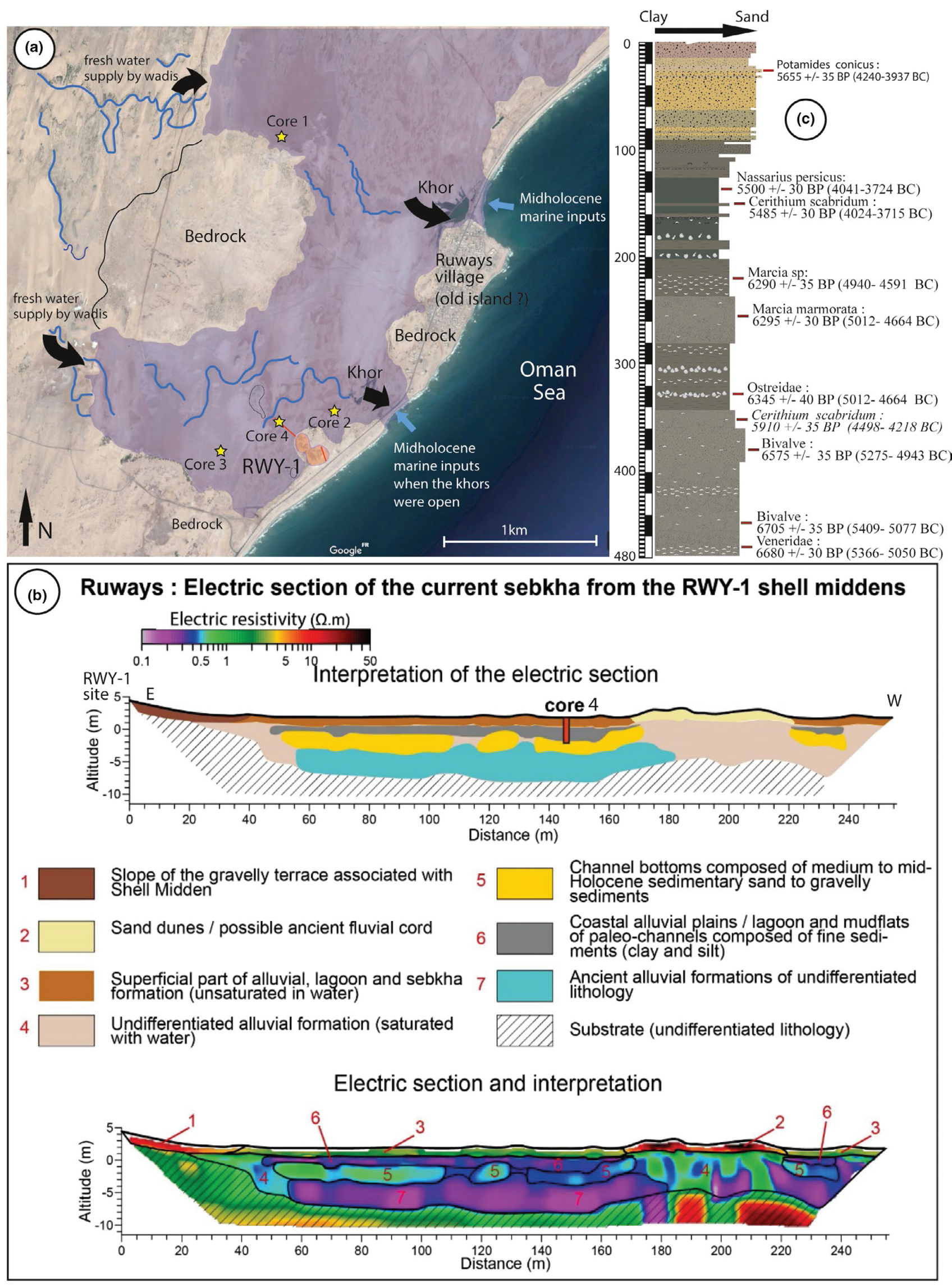


FIGURE $8 \quad$ (a) Map of the Ruways micro-region with the proposed Neolithic extension of a wide open lagoon with mangrove ecosystems (in purple) and the two khors situated on each side of the current village of Ruways, with the position of the four geological core (yellow stars) and the RWY-1 site (orange area). (b) Electrical resistivity tomography section of the current sabkha located in the western part of the RWY-1 site, with the main superficial sedimentary formations and the location of core 4. (c) Lithological sequence of core 4 with the radiocarbon dating series on shells in BP and in cal. yr BC age [Colour figure can be viewed at wileyonlinelibrary.com]

lagoon expansion and the optimum conditions for mangrove forests, which are occupied today mainly by sabkhas (Berger et al., 2013; Glover, 1998; Sanlaville \& Dalongeville, 2005).

To correlate the evolution of the occupation strategies of the RWY-1 site with the local palaeogeographic, eustatic and climato-environmental records resulting from the sedimen tary lagoon, the mangrove and sabkha archives, and the regional data resulting from the archives of the Indian Ocean (marine cores), a systematic off-site geoarchaeological and geophysical survey was made in 2017 and 2018 across the large current sabkha located in the western part of the site (Fig. 8a). This sabkha of more than $10 \mathrm{~km}^{2}$ shows two closed and infilled khors, located on either side of the current vil lage of Ruways, towards which converge the non-perennial and meandriform beds of the two main wadis (Fig. 8a). They were most probably widely open to the Arabian Sea during the middle Holocene, and connected with large lagoons and wadis. We performed electrical resistivity tomography (ERT) across the sabkhas to determine the sedimentary structures and locate the best area for coring operations (Fig. 8b), obtained topographical transects by dGPS to position the ERT profile, the cores, and the current structure of the local landscape, and finally obtained four thermic mechanical corings from depths of 3-5 $\mathrm{m}$ (with a Cobra corer) to obtain a series of the geological archives from the current sabkhas (Fig. 8a). The ERT of the current sabkha has successfully reproduced the geometry of its river-lagoon formations (Fig. 8b). It has distinguished the four main sedimentary units in the upper 10 $m$ filling. A deep, probably late Quaternary, alluvial formation (from -8 to $-3 \mathrm{~m}$ ) is shown in blue, the coarse sandy to gravelly alluvial pre-mid-Holocene formations organised in a succession of paleochannels (around -4 to $-1 \mathrm{~m}$ ) are shown in yellow, the fine fluvial-lagoon silty-sand formations asso ciated with the maximum marine transgression (around - 3 to $+1 \mathrm{~m}$ ) are shown in dark grey, and finally the superficial part of the current sabkha, consisting of red silts and gypsum interbedded with aeolian sands and sometimes dune form ing $(+1$ to $+3 \mathrm{~m})$, is shown in brown. The locations of the cores in the deeper part of the fine fluvial-lagoon formation have confirmed the superficial sedimentary structure of the hinterland sabkha and its absolute chronology by radioear bon dating of shells. One lithological sequence of the $\mathrm{C} 3$ core is presented in Fig. 8c. This confirms the contemporaneous development of an open lagoon associated with a mangrove forest between the second half of the sixth and the end of the fifth millennium yr BC (the subject of ongoing sediment and pollen studies).

\section{CONCLUSIONS}

The current appearance of the shell midden is the result of a long interaction between natural and anthropogenic processes of aggradation and phases of truncation by wind. Only the destruction of half ( $8 \mathrm{ha}$ ) of the RWY-1 shell midden by quarrying activities and the provision of long continuous sedimentary sequences have allowed us to understand and render this long history.

RWY-1 is a site with a long sequence of occupation (6380-3400 yr BC), with probable occupation at the begin ning of the middle Neolithic, which is still unprecedented in Ja'alan in a stratified context (6380-6000 yr BC), but which must be possible to relate to the Neolithic horizons of the wadi Wuttaya dated 6170-5980 yr BC (Uerpmann, 1992), which has close technological similarities with the Pre-Pottery Neolithic B (PPNB) B. They can also be associated with the last Fasad-point industries at sites near Ra's al Jins-37 and Al-Haddah-BJD1 in Ja'alan, which do not have ${ }^{14} \mathrm{C}$ dates (Charpentier, 2008). RWY-1 is also associated with very old Neolithic burials (5300-5200 yr BC) that represent particular funeral rituals under analysis, and presents a great potential to reconstruct the economic strategies of Neolithic coastal populations, which were strongly oriented with the exploita tion of lagoons and mangrove ecosystems (A. Marrast, PhD thesis, and a collective study of the MNHN-Paris team). The lithic industry is based on predominant expedients in the 15 upper units, which contrast with the little elaborate expertise (arrowheads). The combined radiocarbon dates of the shellfish and charcoal, currently being finalised, will make it possible to propose a reference for the micro-regional marine reservoir effect between the end of the seventh and fourth millennia yr BC. Finally, a systematic chrono- and lithostratigraphic study allows us to better determine the evolution of the shell middens, from their building to their partial erosion (site formation processes). The multidisciplinary analysis of this site and the neighbouring geological cores will, in the coming months, allow the first socio-environmental model for the Ja'alan Neolithic to be proposed, with this model covering three millennia.

\section{ACKNOWLEDGEMENTS}

The NeoArabia project is funded by the French National Research Agency (ANR-16-CE03-00007/Neoarabia). We thank the Laboratoire de Mesure du Carbone 14, UMS 
2572, ARTEMIS in Saclay for ${ }^{14} \mathrm{C}$ measurements by SMA in the frame of the National Service to CEA, CNRS, IRD, IRSN and Ministère de la Culture et de la Communication. We also deeply thank the Oman Ministry of Heritage and Culture (Muscat, Oman) for kind permission to conduct field work in the regions of Ja'alan and for their help during field missions, and the French archaeological mission of the MAE (partner of this ANR). We would also like to thank Mr Karl Embleton for his review of the English version and finally the OMEAA platform of the UMR 5600 EVS in Lyon 2 University for its laboratory and field mate rial support.

\section{REFERENCES}

Andrus, C. F. T. (2011). Shell midden sclerochronology. Quaternary Science Reviews 30, 2892-2905.

Azzarà, V. (2013). Architecture and building techniques at the Early Bronze Age site of HD-6, Rā®s al-Hadd, Sultanate of Oman. Proceedings of the Seminar for Arabian Studies 43, 11-26.

Beech, M., Cuttler, R., Moscrop, D., Kallweit, H., \& Martin, J. (2008). Excavation at the Neolithic settlement of MR11 on Marawah Island, Abu Dhabi, UAE: 2004 season. In P. Hellyer \& M. Ziolkowski (Eds.), Emirates Heritage, Proceeding of the 2nd Annual Symposium on recent archaeological discoveries in the Emirates(pp. 25-43). Al-Ain: Zayed Center for Heritage and History.

Berger, J.-F., Charpentier, V., Crassard, R., Martin, C., Davtian, G., \& López-Sáez, J. A. (2013). The dynamics of mangrove ecosystems, changes in sea level and the strategies of Neolithic settlements along the coast of Oman (6000-3000 cal. BC). Journal of Archaeological Science, 40, 3087-3104.

Berger, J.-F., \& Guilaine, J. (2009). The 8200 cal BP abrupt environ mental change and the Neolithic transition: A Mediterranean per spective. Quaternary International, 200, 31-49.

Berger, J.-F., Lespez, L., Kuzucuoğlu, C., Glais, A., Hourani, F., Barra, A., \& Guilaine, J. (2016). Interactions between climate change and human activities during the early to mid-Holocene in the eastern Mediterranean basins.Climate of the Past, 12, 1847-1877.

Berger, J.-F., Metallinou, G., \& Guilaine, J. (2014). Vers une révision de la transition méso-néolithique sur le site de Sidari (Corfou, Grèce): not velles données géoarchéologiques et radiocarbones, évaluation des processus post-dépositionnels. In C. Manen, T. Perrin, \& J. Guilaine (Eds.), La transition néolithique en Méditerranée. Actes du colloque
Transitions en Méditerranée, ou comment des chasseurs devinrent agriculteurs, Muséum de Toulouse, 14-15 avril 2011(pp. 209-228). Toulouse: Editions Errance/Archives d'Écologie Préhistorique.

Biagi, P., \& Nisbet, R. (1999). The shell-midden sites of RH-5 and $\mathrm{RH}-6$ (Muscat, Sultanate of Oman) in their environmental setting. Archaeologia Polona, 37, 31-47.

Biagi, P., \& Nisbet, R. (2006). The prehistoric fisher-gatherers of the western coast of the Arabian Sea: A case of seasonal sedentariza tion? World Archaeology, 38, 220-238.

Binford, S. R., \& Binford, L. R. (1968). N New perspectives in archeology Chicago, IL: Aldine Publishing.

Borgi, F., Maini, E., Cattani, M., \& Tosi, M. (2012). The early set tlement of HD-5 at Ra冈s alHadd, Sultanate of Oman (fourththird millennium BCE). Proceedings of the Seminar for Arabian Studies, 42, 27-40.

Borrell, F., Junno, A., \& Barceló, J. A. (2015). Synchronous environ mental and cultural change in the emergence of agricultural econo mies 10,000 years ago in the Levant.PLoS ONE , 10(8), e0134810.

Bortolini, E., \& Munoz, O. (2015). Life and death in prehistoric Oman: Insights from Late Neolithic and Early Bronze Age funerary practices (4th-3rd mill. BC). In The archaeological heritage of Oman, Proceedings of the symposium held at UNESCO, Paris, September 7th, 2012 (pp. 61-80). Paris-Muscat: UNESCO, Ministry of Heritage and Culture.

Brunet, O. (2015). Les perles en pierre de la péninsule omanaise du Néolithique et de l'âge du Bronze: approche synthétique. Les nou velles de l'archéologie, 139, 12-17.

Buddemeier, R. W. (1978). Sclerochronology: A data source for reef systems models.Atoll Research Bulletin, 220, 25-32.

Butzer, K. W. (2012). Collapse, environment, and society. Proceedings of the National Academy of Science, 109, 3632-3639.

Cartwright, C. (2004). Reconstructing the use of coastal resources at Ra囚s alHadd, Oman, in the third millennium BC.Proceedings of the Seminar for Arabian Studies, 34, 45-51.

Cattani, M., Kenoyer, J. M., Frenez, D., Law, R. W., \& Méry, S. (2019). New excavations at the Umm an-Nar site Ras al-Hadd HD-1, Sultanate of Oman (seasons 2016-2018): Insights on cultural in teraction and long-distance trad®, roceedings of the Seminar for Arabian Studies, 49, 69-84.

Cavulli, F., \& Scaruffi, S. (2012). The Holocene settlement of KHB-1 (Ra's Al Khabbah, Sultanate of Oman): An overview. In J. Giraud, G. Gernez, \& V. De Castéja (Eds.), Aux marges de l'archéologie. Hommage à Serge Cleuziou(pp. 405-429). Paris: De Boccard.

Cavulli, F., \& Scaruffi, S. (2013). Thoughts on nomadism in Middle Holocene Oman. Arabian Archaeology and Epigraphy, 24, 15-27.

Charpentier, V. (2008). Hunter-gatherers of the "empty quarter of the early Holocene" to the last Neolithic societies: Chronology of the late prehistory of south-eastern Arabia (8000-3100 BC).Proceedings of the Seminar for Arabian Studies 38, 93-115.

Charpentier, V., Berger, J.-F., Crassard, R., Borgi, F., Davtian, G., Méry, S., \& Phillips, C. S. (2013). Conquering new territories: When the first black boats sailed to Masirah Island. Proceedings of the Seminar for Arabian Studies, 43, 85-98.

Charpentier, V., Berger, J.-F., Crassard, R., Lacaze, M., \& Davtian, G. (2012). Prehistory and palaeo-geography of the coastal fringes of the Wahiba Sands and Bar al-Hikman, Sultanate of Oman.Proceedings of the Seminar for Arabian Studies 42, 57-78.

Charpentier, V., Blin, O., \& Tosi, M. (1998). Un village de pêcheurs néolithiques de la péninsule d'Oman: Suwayh 2 (SWY-2), première 
campagne de fouille. Proceedings of the Seminar for Arabian Studies 28, 21-38.

Clare, L., Rohling, E. J., Weninger, B., \& Hilpert, J. (2008). Warfare in Late Neolithic/Early Chalcolithic Pisidia, southwestern Turkey: Climate induced social unrest in the late 7 th millennium cal BC. Documenta Praehistorica 35, 65-92.

Cleuziou, S., \& Tosi, M. (2000). Ra's al-Jinz and the prehistoric coastal cultures of the Ja'alan.Journal of Oman Studies 11, 19-73.

Crassard, R., \& Drechsler, P. (2013). Towards new paradigms: Multiple pathways for the Arabian Neolithic. Arabian Archaeology and Epigraphy, 24, 3-8.

Cremaschi, M., Zerboni, A., Charpentier, V., Crassard, R., Isola, I., Regattieri, E., \& Zanchetta, G. (2015). Early-Middle Holocene en vironmental changes and pre-Neolithic human occupations as-re corded in the cavities of Jebel Qara (Dhofar, southern Sultanate of Oman). Quaternary International, 382, 264-276.

Cullen, H. M., Demenocal, P. B., Hemming, S., Hemming, G., Brown, F. H., Guilderson, T., \& Sirocko, F. (2000). Climate change and the collapse of the Akkadian empire: Evidence from the deep sea. Geology, 28, 379-382.

de Beauclair, R. (2008). Funerary rites in a Neolithic nomad community in Southeastern Arabia: The case of al-Buhais 18. Documenta Praehistorica, 35, 143-152.

Fleitmann, D., Burns, S. J., Mangini, A., Mudelsee, M., Kramers, J., Villa, I., ... Matter, A. (2007). Holocene ITCZ and Indian monsoon dynamics recorded in stalagmites from Oman and Yemen (Socotra). Quaternary Science Reviews 26, 170-188.

Flohr, P., Fleitmann, D., Matthews, R., Matthews, W., \& Black, S. (2016). Evidence of resilience to past climate change in Southwest Asia: Early farming communities and the 9.2 and 8.2 ka events. Quaternary Science Reviews 136, 23-39.

Glover, E. (1998). Mangroves, molluscs and man: Archaeological evidence for biogeographical changes in mangrove around the Arabian Peninsula. In C. S. Phillips, D. T. Potts \& S. Searight (Eds.), Arabia and its Neighbours. Essays on Prehistorical and Historical Development\$pp. 63-78). Leuven: Brepols.

Gosselin, M., Lazareth, C. E., \& Ortlieb, L. (2013). Sclerochronogical studies in the Humboldt Current System, a highly variable ecosys tem. Journal of Shellfish Research, 32, 857-882.

Jones, D. S. (1983). Sclerochronology-Rading the record of the mot luscan shell. American Scientist, 71, 384-391.

Kutterer, A.U., Döpper, S., Uerpmann, M., \& Uerpmann, H.-P. (2012). Neolithic cremation in south-east Arabia: archaeological and an thropological observations at FAY-NE10 in the Emirate of Sharjah (UAE). Arabian Archaeology and Epigraphy, 23, 125-144.

Kutterer, A., \& Uerpmann, H. P. (2017). Neolithic nomadism in southeast Arabia-Strontium and oxygen isotope ratios in human tooth enamel from al-Buhais 18 and Umm al-Quwain 2 in the Emirates of Sharjah and Umm al-Quwain (UAE). Arabian Archaeology and Epigraphy, 28, 75-89.

Le Roy Ladurie, E. (1981). The mind and method of the historian Chicago, IL: University of Chicago Press.

Lespez, L., Glais, A., Lopez-Saez, J. A., Le Drezen, Y., Tsirtsoni, Z., Davidson, R., ... Malamidou, D. (2016). Middle Holocene rapid en vironmental changes and human adaptation in Greece. Quaternary Research, 85, 227-244.

Lézine, A. M., Ivory, S. J., Braconnot, P., \& Marti, O. (2017). Timing of the southward retreat of the ITCZ at the end of the Holocene Humid Period in Southern Arabia: Data-model comparison.Quaternary Science Reviews 164, 68-76.
Lézine, A. M., Saliège, J.-F., Mathieu, R., Tagliatela, T. L., Méry, S., Charpentier, V., \& Cleuziou, S. (2002). Mangroves of Oman during the late Holocene: Climatic implications and impact on human set tlements.Vegetation History and Archaeobotany11, 221-232.

Marciniak, A., Barański, M. Z., Bayliss, A., Czerniak, L., Goslar, T., Southon, J., \& Taylor, R. E. (2015). Fragmenting times: Interpreting a Bayesian chronology for the late Neolithic occupation of Çatalhöyük East, Turkey. Antiquity, 89, 154-176.

Marcucci, L. G., Badel, É., Genchi, F., Munoz, O., Todero, A., \& Tosi, M. (2014). New investigations at the prehistoric shell midden of Ra's al-Hamra 6 (Sultanate of Oman): Results of the 2012 and 2013 excavation seasons. In Proceedings of the Seminar for Arabian Studies(pp. 235-255). Oxford: Archaeopress.

Marrast, A., Béarez, P., \& Charpentier, V. (2020). Sharks in the lagoon? Fishing exploitation at the Neolithic site of Suwayh 1 (Ash Sharqiyah region, Arabian Sea, Sultanate of Oman).Arabian Archaeology and Epigraphy, 31, 178-193, https://doi.org/10.1111/aae.12136.

Martin, C. (2005). Stratégies et statut de la collecte des mollusques ma rins sur les sites côtiers d'Oman du Néolithique à l'âge du Bronze: apport des sites de Suwayh 1, Ra's al-Khabbah 1 et Ra's al-Jinz 2. Paléorient, 31, 169-175.

Mashkour, M., Beech, M. J., Debue, K., Yeomans, L., Brehard, S., Gasparini, D., \& Méry, S. (2016). Middle to late Neolithic ani mal exploitation at UAQ2 (5500-4000 cal. BC): An Ubaid-related coastal site at Umm al-Quwain Emirate, United Arab Emirates. Proceedings of the Seminar of Arabian Studies31, 195-210.

Munoz, O. (2017). Transition to agriculture in South-East Arabia: Insights from oral conditions. American Journal of Physical Anthropology 164, 702-719.

Parker, A. G., \& Goudie, A. S. (2008). Geomorphological and palae oenvironmental investigations in the southeastern Arabian Gulf region and the implication for the archaeology of the region. Geomorphology 101, 458-470.

Preston, G. W., Parker, A. G., Walkington, H., Leng, M. J., \& Hodson, M. J. (2012). From nomadic herder-hunters to sedentary farmers: The relationship between climate change and ancient subsistence strategies in south-eastern ArabiaJournal of Arid Environments, $86,122-130$.

Renfrew, C., \& Bahn, P. (2013). Archaeology: The key concepts London: Routledge.

Richard, M., Mercier, N., Charpentier, V., \& Berger, J.-F. (submitted). OSL chronology of socio-ecological systems during the mid-He locene in the eastern coast of the Sultanate of Oman (Arabian Peninsula). Journal of Archaeological Science: Reports.

Saliège, J.-F., Lézine, A.-M., \& Cleuziou, S. (2005). Estimation de l'ef fet réservoir ${ }^{14} \mathrm{C}$ marin en mer d'Arabie. Paléorient, 31, 64-69.

Salvatori, S. (2007). The prehistoric necropolis at Ra's al-Hamra 5 (Muscat - Oman). Journal of Oman Studies 14, 5-202.

Sanlaville, P., \& Dalongeville, R. (2005). L'évolution des espaces litto raux du Golfe Persique et du Golfe d'Oman depuis la Phase finale de la transgression post-glaciairePaléorient, 9-26.

Schöne, B. R. (2008). The curse of physiology-Challenges and opportunities in the interpretation of geochemical data from mollusc shells. Geo-Marine Letters, 28, 269-285. 
Staubwasser, M., Sirocko, F., Grootes, P. M., \& Erlenkeuser, H. (2002). South Asian monsoon climate change and radiocarbon in the Arabian Sea during early and middle HolocenePaleoceanography 17, 15-1-15-12.

Staubwasser, M., Sirocko, F., Grootes, P. M., \& Segl, M. (2003). Climate change at the 4.2 ka BP termination of the Indus valley civiliza tion and Holocene south Asian monsoon variabilityGeophysical Research Letters, 30, 1425.

Tengberg, M. (2005). Les forêts de la mer. Exploitation et évolution des mangroves en Arabie orientale du Néolithique à l'époque islamique. Paléorient, 31, 39-45.

Uerpmann, H. P. (1991). Radiocarbon dating of shell middens in the Sultanate of Oman.PACT , 29, 335-347.

Uerpmann, M. (1992). Structuring the late stone age of southeastern Arabia. Arabian Archaeology and Epigraphy, 3, 65-109.

Uerpmann, M., Uerpmann, H., \& Jasim, S. A. (2006). Funeral monuments and human remains from Jebel al-Buhais, vol. 1. The archae ology of Jebel al-Buhais. Sharjah, United Arab Emirates. Sharjah: Department of Culture and Information.

Usai, D. (2006). A fourth-millennium BC Oman site and its context: Wadi Shab-GAS1. Proceedings of the Seminar for Arabian Studies $36,275-288$.

Wanamaker, A. D., Kreutz, K. J., Schöne, B. R., \& Introne, D. S. (2011). Gulf of Maine reveal changes in seawater temperature seasonal ity during the Medieval Climate Anomaly and the Little Ice Age. Palaegeography, Palaeoclimatology, Palaeoecology 302, 43-51.

Weiss, H., Courty, M. A., Wetterstrom, W., Guichard, F., Senior, L., Meadow, R., \& Curnow, A. (1993). The genesis and collapse of third millennium north Mesopotamian civilizationScience, 261, 995-1004.

Woodroffe, C. D. (1983). Development of mangrove forests from a gee logical perspective. In H.J. Teas (Ed.), Biology and ecology of man groves(pp. 1-17). Dordrecht: Springer.
Zazzo, A., Munoz, O., Beguier, I., Badel, E., Genchi, F., \& Marcucci, L. G. (2016). A revised radiocarbon chronology of the aceramic shell-midden of Ra's al-Hamra 6 (Muscat, Sultanate of Oman): Implication for occupational sequence, marine reservoir age and human mobility. Radiocarbon, 58, 383-395.

Zazzo, A., Munoz, O., Saliège, J.-F., \& Moreau, C. (2012). Variability in the marine radiocarbon reservoir effect in Muscat (Sultanate of Oman) during the 4th millennium BC: reflexion of taphonomy or environment?.J. Archaeol. Sci. , 39, 2559-2567.

Zazzo, A., Munoz, O., \& Saliège, J.-F. (2014). Diet and mobility in a late Neolithic population of coastal Oman inferred from radiocarbon dating and stable isotope analysisAmerican Journal of Physical Anthropology 153, 353-364.

Zielhofer, C., Clare, L., Rollefson, G., Wächter, S., Hoffmeister, D., Bareth, G., ... Weninger, B. (2012). The decline of the early Neolithic population center of 'Ain Ghazal and corresponding earth-surface processes, Jordan Rift Valley. Quaternary Research, $78,427-441$. 